\title{
Establishment of a Simple Separation Process for Highly Pure $\beta$-Carotene from Cultured Carrot Cells
}

\author{
Katsuya Ogawa*, Taku Matsushita \\ and Kazumori Funatsu
}

\begin{abstract}
Dept. of Chem. Eng., Kyushu Univ., Fukuoka 812
Key Words : Biochemical Engineering, $\beta$-Carotene, Plant Cell Culture, Carrot Cell, High Separation Process, Liquid Chromatography

$\beta$ - Carotene sample prepared by the previously reported separation process from cultured carrot cells was found to be pure as a carotenoid pigment but to contain some other lipids. We then improved the separation process by omitting the saponification process and improving the adsorption chromatography and liquid-liquid extraction. This new process markedly reduced the operation time, and highly pure $\beta$ carotene sample which contained no other lipid was obtained while maintaining the previous $\beta$-carotene yield $(5.14 \mu \mathrm{g} / \mathrm{g}$-dry cells $)$
\end{abstract}

* Tokuyama Soda Co., Ltd.

\section{$\mathrm{SO}_{2} / \mathrm{SO}_{3}$ 可逆熱化学反応を用いる密閉系高温 ケミカルヒートパイプの熱輸送特性 ${ }^{\dagger}$ \\ 曽 維平・松田仁樹・架谷昌信 \\ 名古屋大学工学部 化学工学科 $^{\dagger \dagger}$}

\section{緒 言}

筆者らは $\mathrm{SO}_{2} / \mathrm{SO}$ 系可逆反応を熱輸送媒体とするケ カルヒートパイプの研究の第一段として, 前報 ${ }^{1)}$ におい て, 発熱部および吸熱部の反応特性を個別に検討し，そ の結果に基づいて, 密閉系気体循環反応装置を試作し, 熱輸送実験を行った. その結果, 本装置内で実際に連続 的に熱輸送が行えることの可能性を確認した。本報では, 前報で得られた実験結果を踏まえて実験条件を拡張し， 特に密閉系装置での熱輸送限界をさらに詳細に検討する ために，おもに，初期設定温度ならびに循環反応気体流 量などの本熱輸送結果に及ぼす影響について実験データ を補足し，併せて考察を加えた。

† 1990年 9 月 5 日受理 ; 化学工学会第 22 回秋季大会 (東京, 1989年10月）拉よび第 26 回日本伝熱シンポジゥム（仙台, 1989年 6 月）にて一部発表

†† T464-01 名古屋市千種区不老町

\section{1. 実験}

\section{$1 \cdot 1$ 実験装置および方法}

本研究で用いた実験装置ならびに使用した触媒は前報 のあのと同じである. 実験は, 所定の設定温度に保たれ た発熱部, 吸熱部反応管へ $\mathrm{SO}_{2} / \mathrm{O}_{2} / \mathrm{SO}_{3}$ 混合ガスを循環 ポンプを用いて連続的に循環し, 反応に伴うおのおのの 反応管内部触媒充塤層の温度分布ならびに反応器入口, 出口部での反応気体の濃度を測定した。

\section{2 実験条件}

前報では，おもに熱輸送系内反応器の吸, 発熱反応特 性を調べることに主眼がおかれており, 密閉系実験につ いては操作条件が比較的狭い範囲に限られていた。本研 究では，下記に示すように，前報のときの実験条件を拡 げた密閉系実験を行い, 前報で得られた結果を補足する とともに, 本熱輸送特性に及ぼす影響を調べた。実験条 件としては，i）反応気体循環量, $G\left[\mathrm{~kg} \cdot \mathrm{m}^{-2} \cdot \mathrm{s}^{-1}\right] ; 0.21$ 

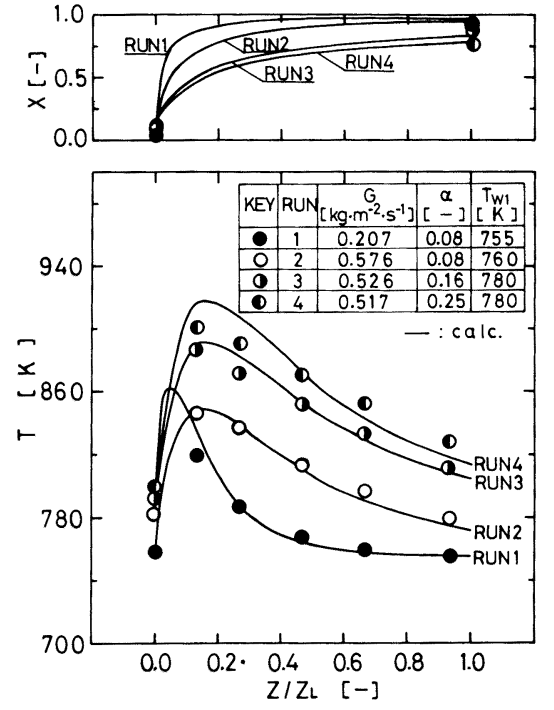

Fig. 1 Temperature and conversion distribution in the axial direction of the bed (reactor I)

$\left.\sim 1.27(0.16 \sim 0.39)^{*}, \mathrm{ii}\right)$ 反応気体組成, $\alpha\left(=\left[\mathrm{SO}_{2}\right] /\right.$ $\left.\left[\mathrm{O}_{2}\right]\right)[-] ; 0.08 \sim 0.25(0.14 \sim 0.25)^{*}$, iii) 発熱側反応管 初期設定温度, $T_{w 1}[\mathrm{~K}] ; 660 \sim 780(710 \sim 750)^{*}$, IV) 吸 熱側反応管初期設定温度, $T_{w 2}[\mathrm{~K}] ; 1120 \sim 1173(1173)^{*}$.

\section{2. 実験結果および考察}

\section{$2 \cdot 1$ 発熱側反応器}

Figs. 1 および 2 亿種々の条件下における発熱側反応 器内の触媒充塡層の定常温度分布と反応器入口, 出口に おりる $\mathrm{SO}_{2}$ の反応率の結果の一例を示す. 触媒は図中, 横軸の無次元距離 0.0 から 1.0 の間に均一に充填されて おり, 触媒充塡層長は $150 \mathrm{~mm}$, 触媒層入口まではアル ミナ予熱層（層長 $150 \mathrm{~mm}$ ) が設けられている。な拉，図 中の実線はいずれむ前報で示したと同様の計算方法を用 いて計算した結果である.

\section{$2 \cdot 1 \cdot 1$ 反応気体循環流量の影響}

Figs. 1, 2 の両図に抢いて, Runs 1, $2\left(T_{w 1} \fallingdotseq 760 \mathrm{~K}\right.$, $\left.T_{w 2}=1170 \mathrm{~K}\right)$ および Runs $3,6\left(T_{w 1}=780 \mathrm{~K}, T_{w 2}=1170\right.$ K) の.結果より，反応気体組成比および反応管初期設定 温度をほぼ同一に保ってガス循環量を増加していくと， 触媒層におけるピーク温度位置は相対的に層下部へ移動 するととむに，層の平均温度は増加している様子か認め られる．乙れはこの程度の循環流量に対して，本実験条 件下では触媒層が十分な $\mathrm{SO}_{2}$ の酸化能力を有しており， 反応量の増大とともに層の発熱量が増加していることを 表している. しかし，Fig. 2 のRun 8 の結果からあ明ら かなように，循環流量をあまり大きくするとガスの予熱

* （）内は前報のときの操作条件
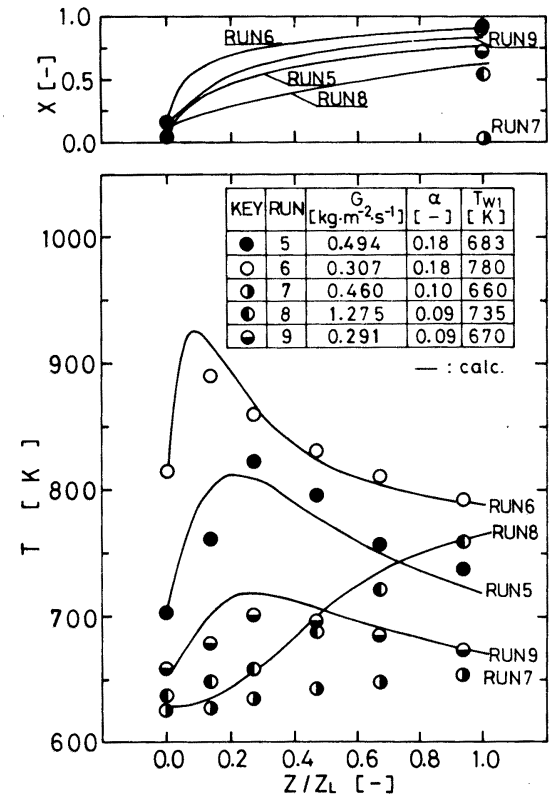

Fig. 2 Temperature and conversion distribution in the axial direction of the bed (reactor I)

が不十分になるとともに滞留時間が短くなるため相対的 に反応が進まず，反応率の低下を招き，十分に熱を取り 出せなくなる。

\section{$\underline{2 \cdot 1 \cdot 2 \quad \mathrm{SO}_{2} \text { 組成比の影響 }}$}

Fig. 1 の Runs 3, $4\left(G_{M} \leftrightharpoons 0.52 \mathrm{~kg} \cdot \mathrm{m}^{-2} \cdot \mathrm{s}^{-1}, T_{w 1}=780\right.$ $\left.\mathrm{K}, T_{w 2}=1170 \mathrm{~K}\right)$ の結果より, $\mathrm{SO}_{2}$ 濃度の増加とと屯に 触媒層温度は増加している, 乙の場合層温度の立ち上が りの様子および層温度のピーク位置に関して両者は循環 流量がほぼ同一なため, ほぼ一致している様子が認めら れる。なお， $2 \cdot 1 \cdot 1$ の場合ならびにての場合ともに層 出口 $\mathrm{SO}_{2}$ 濃度は出口温度を基準として平衡計算から求め た平衡濃度に比較的よく一致するてとを認めた。

\section{$2 \cdot 1 \cdot 3$ 初期設定温度の影響}

Fig. 2 の Runs 5, 7, 9 亿初期層設定温度に対して発熱 反応がどの程度継続しうるかを調べた結果の一例を示す. Run 5 の状態から層初期温度, 循環流量, $\mathrm{SO}_{2}$ 組成をそ れぞれ下げて Run 9 の状態に保っても一応, 反応は行わ れ, 触媒層の $\mathrm{SO}_{2}$ 酸化能力は認められる. しかし, Run 9 の場合に比べて初期設定温度を下げ, Run 7 とすると 反応はもはや行われなくなる. Run 7 の設定条件は循環 流量, $\mathrm{SO}_{2}$ 組成比が Run 9 の場合よりあ大きくなってい るため, 乙れらの比較は直接, 初期設定温度だけの違い を表しているとは言えない.しかし，前述したように， 循環流量ならびに $\mathrm{SO}_{2}$ 組成比がての程度の範囲で大きく なっても触媒層の $\mathrm{SO}_{2}$ 酸化能力はあまり変わらないと考 えられることから, Run 7 で示される結果は初期設定温 

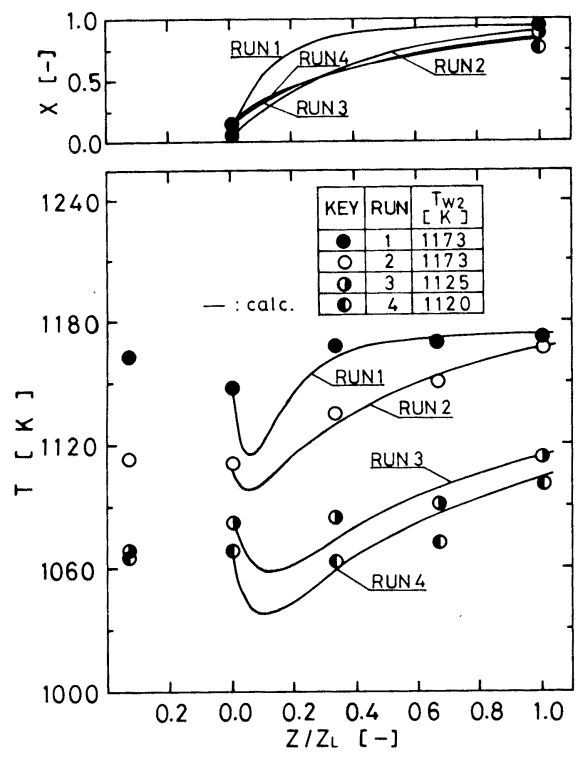

Fig. 3 Temperature and conversion distribution in the axial direction of the bed (reactor II)

度が低すぎるため, 触媒の反応活性が上がらないととを 示していると考えられる.乙れらの結果は本実験の場合， 予熱層の予熱能力とあ関係し, 本熱輸送を考える場合の 検討課題となる.

\section{2 吸熱側反応器}

Fig. 3 亿種々の実験条件に対して得られた吸熱反応器 内の触媒層の定常温度分布と反応器出口 $\mathrm{SO}_{3}$ 反応率の結 果の一例を示す。なお，吸熱側では，触媒層長は 150 $\mathrm{mm}$ ，予熱層は $100 \mathrm{~mm}$ となっている. Run 1 とRun 2 の 結果より, 一定の組成比, 初期設定温度のもとで循環流 量を増加すると吸熱反応量の相違に上って発熱反応器内 の温度挙動とちょうど対称形に, 層極小温度は低くなっ ている。また，Run 1ではほぼ入口より 0.4 の位置まで で反応が完結してるが，Run 2 では触媒層全域で反応が 行われている様子か認められる.

循環流量をほぼ一定とし, 初期設定温度を $T_{w 2}=1173$ $\mathrm{K}$ から $T_{w 2}=1120 \mathrm{~K}$ に下げて, $\mathrm{SO}_{2}$ 組成比を 0.14 から 0.20 亿増加させると, 反応温度は, 大略, 層全体にわた ってほぼ初期設定温度の相違分だけ Runs 1, 2 の場合よ りあ低下している. しかし，てれらの条件に対してあ触 媒層は十分な $\mathrm{SO}_{2}$ 再生能力を有していることがわかる。

\section{3. 熱輸送特性}

Figs. 4 および5にそれぞれ本実験により求められた 単位断面積当たりの反応熱量 $Q_{t}\left(=G_{M} \cdot \Delta H \cdot \Delta X\right)$ と $\mathrm{SO}_{2}$ 循環モル流量の関係打よび反応管 $\mathrm{I}$ の触媒層平均温度上 昇度と $\mathrm{SO}_{2}$ 循環モル流量との関係を示す. 図中, 実線は $\left(T_{w 1}=723 \mathrm{~K}, T_{w 2}=1173 \mathrm{~K}\right)$ 計算より求めた值である.

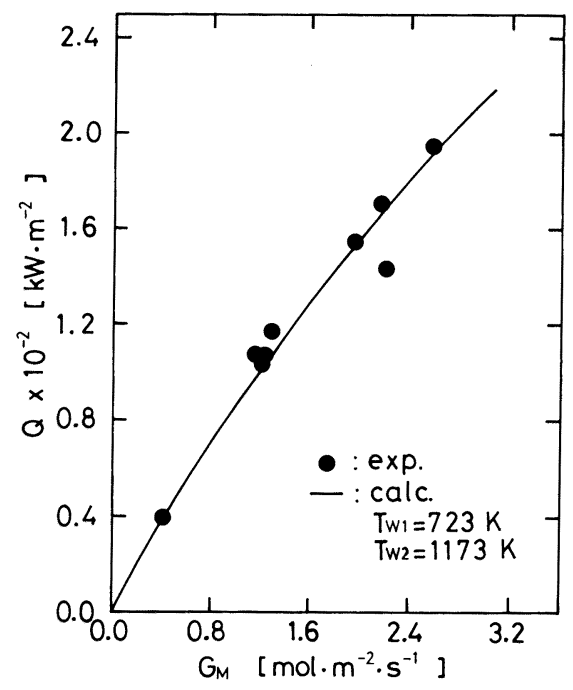

Fig. 4 Relationship between the heat flux released in the bed and the molal velocity of $\mathrm{SO}_{2}$

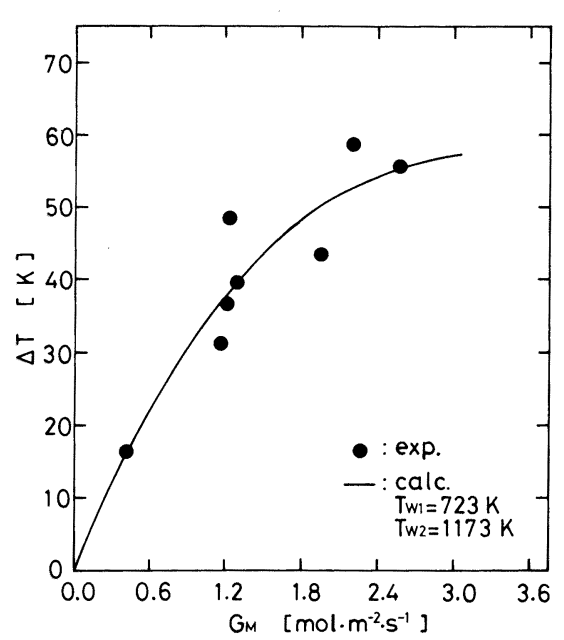

Fig. 5 Relationship between the mean temperature of the catalytic packed bed and the molar velocity of $\mathrm{SO}_{2}$

てれら両図より，本実験で行ったある操作範囲内に扔 いては反応熱量は $\mathrm{SO}_{2}$ のモル流量にほぼ直線的に比例し, 触媒層温度む $\mathrm{SO}_{2}$ のモル流量とともに增加している様子 が認められる. ただし, 層温度上昇の伸びは $\mathrm{SO}_{2}$ のモル 流量に対して鈍くなる．とてろで，2.2であ述べたよう に, 循環がスが大きすぎたり, 初期触媒層温度が低すぎ る場合には熱輸送は事実上行われなくなる，すなわち， 初期触媒層温度が低すぎる場合は触媒は反応活性点に至 らず，反応は起てらない，また，層温度が反応活性点以 上であっても，循環流量が大きすぎると反応率の低下と 同時に反応生成熱量に比べて流体顕熱量の方が大きくな 
り，熱輸送は不可能となる。

以上のてとから, 本熱輸送法を可能とするためにはで きるだけ低温度域において反応活性を有する高性能触媒 の選択あるいは開発, 触媒層の伝熱促進, 熱交換技術, さらには触媒層出口ガス顕熱の回収（たとえば反応管入 ロガスと出口ガスの熱交換）などが今後の研究課題にな ると考えられる。

\section{結 言}

$\mathrm{SO}_{2} / \mathrm{SO}_{3}$ 系可逆反応を熱変換, 熱輸送媒体とする化 学熱輸送法に対して, 熱需要部, 熱供給部における触媒 充填層の反応, 伝熱挙動を調べた。 その結果, 本実験範 冓内では, 循環気体流量および触媒層温度を適当に選べ ば, 両反応管において $\mathrm{SO}_{2}$ の酸化あるいは $\mathrm{SO}_{3}$ の分解 反応を安定して継続的に行えるてとが認められた。さら に, 反応熱量および触媒層温度上昇と気体循環流量との 関係より, 本反応系の熱輸送特性を検討し, 今後の開発 目標を明らかにした。

\section{Nomenclature}

$G=$ mass velocity of fluid

$\left[\mathrm{kg} \cdot \mathrm{m}^{-2} \cdot \mathrm{s}^{-1}\right]$

$G_{M}=$ molal velocity of $\mathrm{SO}_{2}$ $\left[\mathrm{mol} \cdot \mathrm{m}^{-2} \cdot \mathrm{s}^{-1}\right]$

$Q_{t}=$ quantity of reaction heat

$\left[\mathrm{W} \cdot \mathrm{m}^{-2}\right]$

$T=$ central temperature of the catalytic

packed bed

$T_{w 1}=$ temperature of outer tube at the wall in $\mathrm{SO}_{2}$-oxidation reactor

$T_{w 2}=$ temperature of outer tube at the wall in $\mathrm{SO}_{3}$-oxidation reactor

$X=$ conversion of $\mathrm{SO}_{2}$ or $\mathrm{SO}_{3}$

$Y_{A 0}=$ molal fraction of $\mathrm{SO}_{2}$

$Z$ = axial distance in the catalytic packed bed

$Z_{L}=$ length of the catalytic packed bed

$\alpha=$ ratio between molal fraction of $\mathrm{SO}_{2}$ and $\mathrm{O}_{2}$

$\Delta H=$ heat of reaction

$\left[\mathrm{J} \cdot \mathrm{mol}^{-1}\right]$

$\Delta T=$ mean temperature difference of the catalytic packed bed between the initial temperature

$\Delta X=$ conversion difference of $\mathrm{SO}_{2}$ between the inlet and outlet of $\mathrm{SO}_{2}$-oxidation reactor

\section{Literature cited}

1) Zeng, W.P., H. Matsuda and M. Hasatani: Nippon Kagaku Kaishi, No. 8, 1267 (1988)

\title{
Heat Transportation Characteristics of High- Temperature and Closed-System Chemical Heat Pipe Which Uses $\mathrm{SO}_{2} / \mathrm{SO}_{3}$ Reversible Thermo- chemical Reaction
}

\author{
Zeng Wei-Ping, Hitoki Matsuda and Masanobu Hasatani \\ Dept. of Chem. Eng., Nagoya Univ., Nagoya 464-01
}

Key Words : Reversible Thermochemical Reaction, High-Temperature Heat Transportation, Chemical Heat Pipe, Catalytic Reaction, Catalyst Fixed Bed

From the viewpoint of high-temperature energy transportation, a fundamental study of a chemical heat pipe which uses the $\mathrm{SO}_{2} / \mathrm{SO}_{3}$ reversible thermochemical reaction is carried out in a closed system consisting of exothermic and endothermic reactors.

For a relatively wide range of circulating gas flow rate, the gas composition, and initial temperature of the catalyst fixed bed, it is found that $\mathrm{SO}_{2}$ and $\mathrm{SO}_{3}$ of nearly equilibrium concentration could be circulated between the $\mathrm{SO}_{2}$-oxidation and the $\mathrm{SO}_{3}$-deoxidization reactors. Further, the possibility of continuous thermal energy transportation by use of this system was determined. The heat transportation characteristics of the system is made clear by the relationship between the heat flux released from the catalyst fixed bed and the molal velocity of $\mathrm{SO}_{2}$. 